\title{
The Resistance of New Zealand POWs in Asia during the Second World War
}

\author{
MATT JOHNSON
}

\begin{abstract}
This article examines the New Zealand prisoner of war experience in Asia during the Second World War. Even though conditions were deplorable, POWs engaged in acts of resistance. While some accounts described overt actions that realigned experiences with traditional narratives of wartime contribution, this paper analyses the impact of subtler actions, such as stoicism in response to physical punishment, a refusal to accept the bleakness of their surrounds, and taking their survival into their own hands by instituting basic medical practices. These acts of resistance helped prisoners to imbue their ordeal with meaning by combating the enemy in the only terms available to them.
\end{abstract}

When Japan launched a surprise attack on Pearl Harbour on 6 December 1941, James Bertram was living in Hong Kong. He was employed as a relief worker for the China Defence League, and he remembered looking at his surroundings on the previous evening and thinking that "never had the blue outline of its hills looked more peaceful." After the outbreak of war, he joined the Hong Kong Volunteer Defence Force, but quickly became one of the approximately 377 New Zealanders who were captured in Asia during the Second World War. ${ }^{2}$ This number included about 100 servicemen, and stood in stark contrast to the more than $8000 \mathrm{New}$ Zealanders who were captured in Europe. ${ }^{3}$ The experiences of these prisoners differed greatly based on whether they were military personnel or civilians, with even more variance occurring because of their respective ranks or occupations. Nevertheless, all captives had to suffer through the uncertain duration of their imprisonment, monotony and isolation from their loved ones back home. Moreover, in most cases they experienced a subversion of their previously held beliefs. Bertram summarised this feeling as he remembered that his surrender was an unforgettable experience, when "Over-night we had been turned from men with a purpose into figures of ridicule."4

While the individual ordeal of POWs (prisoners of war) in Asia differed, depending on their service, rank, and which camps they were sent, there were several common themes. They were surprised to be captured; they were disconnected from their loved ones back home; and they were subjected to or witnessed mistreatment from the guards. Through an examination of Bertram's and other POWs' accounts, this article argues that even in these brutal conditions New Zealanders employed subtle forms of resistance against their captors. Mostly, these conformed to traditional acts of rebellion, such as sabotaging work placements or reintroducing recreational activities. However, this paper also examines three actions less commonly described as resistance: a stoicism to physical punishment; a refusal to accept the bleakness of their surrounds; and taking their survival into their own hands by instituting basic medical practices. These acts of resistance helped prisoners to imbue their ordeal with meaning, by combating the enemy in the only terms available to them.

This article draws upon two sets of primary sources to illustrate the resistance attempts of New Zealand POWs. First, memoirs written after their liberation. These sources vary in terms of 
distance from the authors' ordeal, but the lack of in-the-moment accounts, such as diaries, means that these accounts sometimes provide the only glimpse into captivity in Asia. In many cases, these accounts differed from European memoirs. European accounts often dropped the reader immediately into the action and ended shortly after the author's liberation, whereas Asian memoirs usually featured long descriptions of life before and after the war. This could be seen as another form of resistance, because the subject remained unwilling to be totally defined by their captivity; other aspects of their life were just as noteworthy. Second, this paper employs testimony from the United Nations War Crimes Commission. These were more contemporary sources which were often created shortly after the prisoners' release. There was a rawness to these accounts as they portrayed the harsher aspects of captivity.

Historians have discussed the ways that prisoners, especially those who were imprisoned in Asia, were reluctant to share their stories, because they could not reconcile their experience of captivity with stereotypical wartime narratives that emphasised bravery and sacrifice. ${ }^{5}$ Brian MacArthur noted that POWs "were so scarred by their experiences - most for life - that they could not discuss them even with their wives and close family. They believed that their experiences at the hands of the Japanese were, literally, incomprehensible." ${ }^{6}$ Christina Twomey has argued that Australian POWs remained reluctant to share their experiences until the 1980s, when the acceptance of trauma as a subject helped legitimise narratives of suffering. ${ }^{7}$ While prisoners from other countries may have found it hard to discuss their captivity, New Zealanders seemed to be more inclined to express themselves. Bertram's account was published in 1947, and the war crimes files feature at least 33 individual testimonies, representing a significant proportion of the New Zealanders captured in Asia. New Zealand POWs were also receptive to a request made by $\mathrm{W}$. Wynne Mason to answer surveys about their experience. As a former prisoner himself, Mason was compiling information for the official war history, and he implored others to ensure that there was a "true and accurate" account which covered "all aspects of prisoner of war experience, capture, life in camps, escapes, liberation, repatriation and rehabilitation." 8 There were 102 responses from New Zealanders who were imprisoned in Asia. ${ }^{9}$ This helped Mason produce a volume for the country's official war history devoted to the POW experience. Although some POWs featured in both the surveys and the war crimes testimonies, the combined data set signified that a large proportion of New Zealanders who were prisoners in Asia were willing to share their experiences.

As previously mentioned, the New Zealanders who were imprisoned by the Japanese were a mixture of servicemen and civilians. Capture came as a surprise to most, especially those who were in the Pacific before the start of hostilities. Gladys Tompkins had been working as nurse in Malaya since 1939 and continually described the beautiful landscapes she encountered. While vacationing on a rubber estate she noted that their house was "surrounded by flowering trees and shrubs, with a huge pink kind of Acacia tree in full flower just outside our window. In other parts of the garden were groups of pink and white Frangipani trees, whose attractive scent filled the air." 10 Later, she took a train to Kuala Lumpur and remembered "its anti-glare windows, full air-conditioning, luxurious carpets and comfortable chairs. It was only necessary to ring a bell for anything one needed." 11 This peaceful experience was shattered by the arrival of war, and stood in contrast to what she witnessed while working in Singapore, when the Japanese attacked the area. Tompkins recalled the "Terrible wounds and confusion everywhere, dead lying along corridors, patients two in a bed and someone under it, some dead and some alive, and the smell from the wounds and other things was revolting."12 Even when their capitulation was imminent, Tompkins continued to believe that Singapore could not fall. She 
imagined that she would be able to carry on nursing in the hospital, but this dream was crushed when the surrender was announced, and all the staff and patients were ordered to transfer to another hospital on the other side of Singapore. ${ }^{13}$

For Tompkins, her transition - from an authority figure who was charged with caring for the ill and, to some extent, spreading western medical practices to Asia-was a subversion of the accepted racial hierarchy. Numerous studies have explored the role that race played in intensifying the confusion and humiliation of white soldiers and civilians when they were captured by people who they viewed as inferior. ${ }^{14}$ This narrative was present in both New Zealand official histories and personal testimonies. When describing his capture in Singapore, Captain John Mackie asked readers to imagine:

a captured soldier who is imprisoned, not behind bars, but barbed wire in squalid conditions in the germ-proliferating tropics with no normal amenities. His guards are not state employees answerable for their behaviour, but brutal and arrogant Asians who suffer from delusions of being a divine master race whose prerogative is to mete out harsh mental and physical punishment to despised European prisoners for trivial or imaginary misdemeanours. ${ }^{15}$

More simply, he described Japanese as "sub-human" who were eventually "beaten by better military commanders, better technology and better service personnel." ${ }^{16}$ Furthermore, the New Zealand official history argued that "Some part of the blame for the slow starvation of their prisoners must be attributed to the differences in racial standards, though nearly everywhere it was due far more directly to a cynical disregard of every humane consideration and an active desire first to humiliate and then to destroy their victims." 17 These accounts emphasised the foreignness of captivity in Asia. And as Mackie suggested, the strangeness was not only that of being disempowered by a non-white race, but also that people's perspective of their surroundings changed: no longer were they in a tropical paradise, they were in a dirty and uncivilised world.

While race was prominent in most New Zealand accounts of captivity, Bertram was more circumspect. He noted that while the Japanese acted inhumanely, their actions were a result of a political ideology which could infect any society because it "lives on terror, and breeds monsters like Kramer and Tokuda just as dung breeds flies. And the whole thing isn't washed out when a few of the leading butchers have been shot or hanged."18 Nevertheless, Bertram struggled to comprehend how his life had been turned upside down. The immediacy of his capture meant that he had "barely time to realise that we were prisoners." ${ }^{19}$ When Bertram was moved from his camp on Hong Kong Island to Kowloon, he remembered feeling elated at the familiar sight of "the barrack huts, spaced as rigidly as tent lines, ... long, low affairs with concrete floors." ${ }^{20}$ However, like other accounts which described the foreignness of captivity, his elation was temporary. When he saw the camp up close "the picture abruptly changed. The barracks had been one of the first targets of the Japanese air attack. . . And far more disastrous than any bombs had been the ravages of looters, who had swarmed into the camp after the British garrison withdrew from Kowloon." 21

In the years following their capture, New Zealand POWs suffered the well-known brutal aspects of captivity in Asia. Conditions varied widely based on the location of the camp and duration of captivity, but across the accounts of POWs are constant malnourishment and occasional mistreatment. Furthermore, unlike their counterparts in European camps, prisoners in Asia were 
unable to supplement their diet with care packages from the Red Cross. These parcels, which included food and other items, were sent to prisoners in both theatres of war, with most POWs imprisoned in Germany and Italy citing these packages as essential to their physical and mental survival. However, New Zealand POWs in Asia noted that they received none or few Red Cross parcels, which contributed to them continually referencing the lack of food, as well as lamenting that their diet was almost entirely rice based. Signalman Nathan Jaffe remembered that at Macassar "the food situation became so bad that prisoners were reduced to eating dogs, cats, lizards, tortoises and also eating from the Japanese garbage tins. The Japanese made every effort to prevent us from getting any extra food." 22 The Japanese used these shortages to incentivise POWs into working parties. Flight Officer Donald Duff noted that at Haruku, workers received more rations, but since these supplies were coming from a fixed pool, it meant less for others. ${ }^{23}$ Nevertheless, even if working afforded POWs additional supplies, it was still not adequate for the jobs required of them. Sergeant Guy Herdman noted that his assignment at the aerodrome at Hong Kong was labour intensive, and he often started work exhausted and "physically weakened by lack of sufficient food." 24

Although the inadequate provision of supplies and overcrowded living conditions could be blamed on a lack of foresight or ability to care for large numbers of prisoners, there were numerous cases of physical violence against New Zealand POWs which were more deliberate. The most significant event was the execution of seventeen coastwatchers on Tarawa after an American air raid on the island. ${ }^{25}$ Others died in captivity, but often as a result of illness rather than violence. Still, Meredith noted that POWs suffered minor to moderate assaults for a variety of misdemeanours, such as being slapped or punched for failing to salute their captors. ${ }^{26}$ Sergeant Robert Ravenwood remembered that while he was working at the Changi Aerodrome he was beaten with bamboo rods. He did not know why he was punished, but was "under the impression that the beatings were given by the Guards to show their authority over the Prisoners." 27

Although physical punishments were brutal, prisoners sometimes sought to recast these events in their memoirs by emphasising their defiance. Duncan McCallum recalled working at the Mitsubishi shipyards in Yokohama when a guard punished a prisoner for talking to a Japanese worker. The guard punched the prisoner, eventually knocking him to the ground. However, McCallum noted that the POW refused to stay down. Each time it looked like the punishment was finished "he staggered back on to his feet again" only to be knocked down again. ${ }^{28}$ Similar refusals to submit were noted by other prisoners across Asia. Flight Lieutenant Ronald Miller remembered that prisoners were beaten at Java before they were sent to neighbouring camps. He described the beatings as methodical, as each prisoner was assaulted in order as the column left the camp. Similar to the previously described beating, some prisoners were knocked to the ground. However, Miller noted that he was one of the last POWs to leave, so when it was his time to be attacked the "guards were getting tired and were using sand shoes with which to strike the prisoners." Nevertheless, Miller recalled he was struck about forty times across the face, but, importantly, he was not knocked down. ${ }^{29}$ This was a small moment of triumph amidst a tragic scene of inhumanity. Miller's statement suggested that he found comfort in realising that the guards' power lay in their position, not in their physical superiority. His refusal to fall to the ground was an attempt to resist the power relationships of captivity.

Seeing another POW refuse to submit to Japanese punishments inspired other prisoners to act similarly when they were assaulted. Jaffe remembered that his camp was forced to watch as a 
prisoner was struck with a club. He noted that a POW normally would "fall over after receiving about 30 or 40 blows from the club but Wilkinson refused to fall." ${ }^{30}$ Jaffe proudly counted the blows, noting that the prisoner was struck 205 times and the guard was too tired to carry out the punishment alone. The prisoner was praised for his toughness and his achievement of still standing on his feet after the assault. Although Jaffe was proud of this man's stoicism, he disabused any notions that this resistance was easy or glorious. The prisoner was unable to work for months and his "buttocks were beaten to a pulp and were a mass of lacerated flesh." ${ }^{31}$ Later in the war Jaffe was working at a Japanese Navy garage in Macassar when he was beaten for buying food from a civilian. Jaffe received about 40 blows with a club, but rather than continue to be assaulted, he noted that he "fell deliberately. I considered I had had enough." 32 Unlike the reactions of the POWs which have been described above, Jaffe had no interest in risking further bodily harm by refusing to bend to his captor's will. Still, he framed his submission not as a defeat, but as a choice. Even though he was powerless, he decided when his punishment ended. Notwithstanding the postwar desire of some POWs to emphasise a sense of stoicism to these beatings, physical assaults damaged more than the men's bodies; the fear of future attacks mentally drained them. Combined with the inadequate living conditions, the prospect of an unprovoked beating added to an atmosphere of dread. L. S. Jones was horrified at what he encountered at Taiping, noting that he would "never forget the look in the eyes of some of the newest arrivals - they were like those of a hunted animal." ${ }^{, 33}$ Similarly, Flight Lieutenant Cliff Emeny remembered that when he entered Rangoon prison he saw "haggard men, just skin and bone, dressed only in a loincloth hanging to them by a string. The sight of them, cowed, bent and stealing only a brief glance at us, created an atmosphere of awful terror filling that place." ${ }^{34}$ When Emeny looked at these men he realised that the harshness of captivity could easily turn him into one of these pitiful figures. He recalled that it was at this moment that it became "obvious the Japanese couldn't have cared less whether we survived or not. Our lives meant nothing to them, so I devoted myself to survival." ${ }^{35}$ In the case of POWs, survival was the ultimate form of resistance, but for many prisoners this was reliant on maintaining their mental well-being. Bertram noted that this was difficult because the most damaging part of Japanese camps was not physical, it was what prolonged exposure to these conditions "threatened to do to our minds." ${ }^{36}$ Nevertheless, Mackie argued that although brutal acts occurred regularly, focusing on them gave "a false impression of their place in the overall picture of captivity under the Japanese." ${ }^{37}$ He believed that a balanced portrayal of the POW experience needed to include their resistance efforts. ${ }^{38}$

Even though conditions were often considerably worse in Asian POW camps than in European ones, prisoners still found ways to resist their captors. ${ }^{39}$ In European accounts, resistance often centred on attempts to escape the camps. However, escape from Asian camps was far more difficult due to language differences, geography, fear of fatal reprisals against themselves and their fellow POWs, and, perhaps more than anything, an inability to blend into Asian communities while on the run. These barriers were cited when Lieutenant Commander Ralph Burton Goodwin remembered that during his experience in Hong Kong he encountered few prisoners, even amongst officers, who were willing to attempt an escape. ${ }^{40}$ However, Goodwin did not share this pessimism and remained committed to trying to escape, although he was conflicted because his attempts "might bring suffering on the heads of those left behind and, of course, one might die. The rewards for the successful break, against which the dice were heavily loaded, were freedom and a chance to hit back at a hated enemy." ${ }^{41}$ After years of planning his escape, Goodwin managed to break out of his camp in Hong Kong and eventually made it back to friendly territory. Although Goodwin's story was an uplifting tale of overcoming immense 
odds, most New Zealanders did not escape from their camps in Asia; instead, their discussions about this act of resistance were restricted to when they were coerced to sign a no-escape pledge. Bertram remembered that in Hong Kong he initially refused to sign the form, because it was a chance to contest the authority of the guards. ${ }^{42}$ Similar acts of defiance occurred throughout camps in Asia, but the Japanese responded by placing prisoners into overcrowded facilities without supplies until they relented. Meredith remembered that at Singapore, 17,000 POWs were forced into Selerang Barracks until "Conditions became so bad that we were finally told to sign the forms to give us some relief." 43 In Meredith's recollection his decision to surrender was not his own; thus, he could distance himself from the associated shame of having succumbed to the Japanese again. Similarly, when Mackie signed the no-escape pledge he noted that his commander took responsibility for their capitulation. However, unlike Meredith, he argued that this technicality did not reduce his personal shame: he had still sacrificed his honour. ${ }^{44}$ Nevertheless, the POWs reclaimed some aspect of their pride, with Mackie noting that "the promise we signed was not worth the paper it was written on and was totally despised by all." 45 Bertram also remarked that when he signed, he did so "as viciously and illegibly as I could." 46

Sabotaging work placements, a common act of resistance in European camps, was also undertaken by prisoners in Asia. Claude Thompson remembered that if his group finished their work early it resulted in them being tasked with more duties the next day. Therefore, he noted that they decided to work:

as slowly as we dared, always watching the guards so that they wouldn't catch us loafing. As the guard looked our way we did a few strokes, but as soon as his back was turned we stopped. I soon decided that the only way to exist on these working parties was to avoid hard work as much as possible, and by continuous vigilance I did the minimum. ${ }^{47}$

The important aspect of this statement was the agency which working slowly represented. Life in captivity was rigid, but the chance to participate in an act of sabotage, no matter how insignificant, was an opportunity to assert oneself. Similarly, Major Robert Horker testified that while working as supervisor at a tool-making factory he instituted a scheme to disrupt the facility's output. He described "the organised 'go slow' policy of all P. O. Ws, which was so successful that I can truthfully record that the average American or British prisoner produced in work no more that $30 \%$ of what he was capable in the circumstances." 48 In this instance, Horker tried to reduce his shame of working for the enemy by connecting his experience with the wider war effort. When he recast his captivity as a series of deliberate acts to sabotage the enemy, he was no longer a powerless spectator, he was making a wartime contribution.

Not all prisoners sabotaged their work placements or felt ashamed of working. Those who were tasked with medical duties took great pride in their efforts to help the ill and limit the spread of diseases. This work ranged from formalised positions in camp hospitals, as well as informally caring for other prisoners. Emeny remembered that it was essential for prisoners to take responsibility for their own medical services, because they received little to no help from the Japanese ${ }^{49}$ He noted that dysentery was particularly debilitating, especially with no medicine available to treat the illness. Instead, he had to manufacture a treatment plan to cure these cases. Emeny settled on a plan of limiting the patient's food intake, to the point of starvation, for several days, then gradually reintroducing solid foods. He admitted that his system was crude, but it "worked and by this treatment we never lost another man to dysentery. When you consider 
how ill some of the men were when they came over from the cell block it is understandable why we felt such a sense of achievement." ${ }^{50}$ A similar treatment was implemented when beriberi became rampant in the camp, with salt being removed from the men's diet. ${ }^{51}$ Emeny and other prisoners' ability to develop ways to manage illnesses was a tangible reminder of their agency, even in a restricted environment. Moreover, it showed their willingness to endure, and reinforced that sometimes the only way to resist was to survive.

While planning a physical escape attempt or sabotaging a work placement was an overt act of rebellion, New Zealand prisoners in Asia also participated in less aggressive forms of resistance. Robert S. La Forte argued that these acts were fairly common, because maintaining self-respect was a form of resistance which entailed "not giving in to one's sorry predicament, keeping one's mind off his troubles, and not becoming melancholy." ${ }^{.52}$ POWs participated in a variety of leisure activities to reclaim aspects of their identities and regain control of their limited free time. Kevin Blackburn noted that sport was particularly important to restoring the POWs' self-worth, because it was "a way to prove to themselves and their comrades that they were still strong and fit men rather than a dejected ramshackle group of stragglers who had entered Changi as prisoners after having suffered loss upon loss to the Japanese."53 Midge Gillies contends that while these acts of resistance have been neglected in favour of more overt actions, it is necessary to recognise the "men who stole back time from their captors through creativity." 54

Moreover, resisting could consist of reasserting aspects of self. Captivity was largely uniform: from the outside, prisoners were scarcely different from one another. They received the same food, were allocated the same clothes and slept in overpopulated barracks. However, Emeny recalled how personalities were reintroduced into camp life through daily discussions. His group started a routine where a prisoner "would give a talk about himself; where he lived, where he went to school and some information about his family, occupation and religion.... These sessions were not only educational but also did wonders to get one's mind off food and our dangerous existence." 55 This may seem like an insignificant action, but within the context of a POW camp, reintroducing civility and forming bonds between prisoners offered a reprieve from their situation. Mackie reasoned that they could not physically resist their captors: they "could only wait, try to stay alive and sane, and hope." ${ }^{, 56}$ Thus, he maintained that discussions were instrumental to survival, because they were a means to escape:

into the mind where one could go back home and imagine all the good things of earlier freedom-kindness, a good bed and food, one's friends, and all the amenities of a civilised life. We used to sit around and talk about food, conjuring up the kind of meals we would like to have, the books we would like to read and the things we would do if free. ${ }^{57}$

Part of the appeal of talking with other prisoners was the discovery that there were people in captivity with immense knowledge. Jones remembered that his group would often sit in the yard at Changi after dark discussing "every subject under the sun, our work, our play, places we had visited, religion, politics, the brave new world we hoped to see when all the current foolishness had ended.... Some of these discussions were intensely interesting as among the half dozen or so in my particular group were people who had seen most parts of the world and had experienced most things." ${ }^{58}$ Tompkins recalled a similar feeling of joy when she noted that for a short period of time the Japanese allowed prisoners from the men's camp to give lectures on "every subject imaginable such as astronomy, anthropology, religion, Portuguese 
colonisation, evolution, history of sociology in Great Britain during the last one hundred years, and many other things." 59

In some cases, these informal discussions became formalised with the establishment of educational classes. Mackie noted that the learning programs at Changi "filled a need in the barren existence of the incarcerated. It was also amazing to find how many people had earlier specialised in learning about some particular subject and willingly shared their knowledge to make life less unbearable for others." ${ }^{60}$ Even when he moved camps, learning remained a favourite pastime, because he believed that the "combination of deteriorating physical and mental states was truly a deadly one. We could do little about improving our physical condition, but with determination and encouragement, everyone was free to exercise his mind without needing extra food." ${ }^{61}$ Still, he was quick to reprimand readers if they thought "our POW classes were endowed with classrooms, desks, blackboards, chalk and other useful adjuncts.... We had none of these and damn-all of anything else but hard to come by scrap paper, scarce pencils and home made ink of dubious quality." 62

Other prisoners simply enjoyed mentally retreating from their immediate reality through reading and writing. MacArthur argued the books were treasured possessions which were "read and reread" because they offered a personal solace from the mass experience of captivity. ${ }^{63}$ Tompkins noted that "It cannot be estimated what a help these books were in the life of the camp, giving mental relaxation to the mind." ${ }^{\prime 4}$ Likewise, Thompson welcomed the chance to read, because without books he could only think about his situation. ${ }^{65}$ Although he was suffering physically and mentally, his desire for knowledge was a space where he could exert control. He escaped into the stories written by James Joyce, H. G. Wells and Eric Linklater. Moreover, while he was at Haruku, he became captivated by a book about yoga. He tried to practise some of the techniques, but found it difficult to learn because of the constant presence of other prisoners. Eventually he was able to find a quiet room where he sat "crosslegged in the correct fashion" and "tried to do the breathing and meditation exercises." 66

New Zealand POWs also wrote diaries during their captivity, even though these were often prohibited. Duff proudly proclaimed that although the Japanese conducted frequent searches for contraband his diary remained secret ${ }^{67}$ This form of writing was important and showed a willingness to not only document one's experience, but also to resist the enemy by ensuring it remained hidden. However, a more effective means of resistance was poetry. Philippa Kelly argued that mental activities had a limited impact on the prisoners' ability to escape their depressing surroundings, because:

Things are as they are experienced; and no matter how one tries to divert oneself through visions of extravagant dinners back home, faces of loved ones, blooms of roses in a soft wind that defy the suffocating, sultry air of Changi, these images are never enough. They serve only to distract, as one might be momentarily distracted by a story or a dream. ${ }^{68}$

Nevertheless, she suggested that prisoners continued to write and read poetry because the physical restrictions of captivity had "strong metaphorical connotations for the mental constraints they felt. Cooped up in Changi, these soldiers used Shakespeare and other literary classics as material for poetry that, at least partly, freed their spirits." ${ }^{69}$ Bertram noted that a shared love of poetry was the basis for his most enduring friendships as a small group of prisoners, known as the Shumshuipo Parnassians, met "regularly in various places to read, write 
and discuss English verse." ${ }^{, 70} \mathrm{He}$ admitted the group's poetic output "may not have been remarkable for quality - in quantity it was surprising - it must have meant something to each of us, for we kept up our meetings through many vicissitudes, until our small company was finally torn asunder by a draft to Japan." "71 It was admittedly a small act of resistance, but the men's willingness to document their experience through a passion which they enjoyed was a reminder of who they were before imprisonment. Although these bonds were temporary, for those brief moments when the Shumshuipo Parnassians met there was a sense of belonging which made captivity slightly less isolating.

Another common creative outlet for POWs was theatre productions, albeit not to the frequency of their European counterparts. Still, Tompkins remembered that at Changi "It was wonderful that so many people could forget their troubles in a place like that and put their minds, originality, energy and pluck into organising these things." 72 Mackie went into further detail about the productions at Changi, noting that the plays were staged in a makeshift open air cinema. ${ }^{73}$ Against the backdrop of the restrictions of captivity, the theatre became a space where prisoners could briefly forget about the privations of their daily lives. The physical torment resulting from unpredictable guards and inadequate food did not disappear entirely, but watching a play or listening to a concert allowed the POWs' minds to be free. Mackie recalled that one rendition of I Believe, Danny Boy resonated with him, because:

The ambience was so different from that of our usual lifestyle at Changi. One or two excellent violinists stirred the emotions and tugged the heartstrings with their playing. All these talented people deserved deep thanks for providing an hour or two, on occasion, when one could completely forget the surroundings and the precarious state of existence inflicted upon us. ${ }^{74}$

Continuing the theme of creating a mental enclave to resist the pressures of captivity, some prisoners noted that they refused to be consumed by the privations surrounding them; instead, they sought comfort in moments of natural serenity. Thompson remarked that the conditions at Haruku hospital were deplorable and that the "stench of a hut full of men suffering from dysentery who have no means of cleaning themselves properly is something that has to be experienced to be believed."75 Nevertheless, he recalled that:

For anyone who could forget the squalor and misery on Haruku there was beauty to enjoy in abundance. The sparkling calm sea with its wonderfully coloured coral was a joy to look at. Sunsets were breathtakingly lovely, but few saw them. I did, and I am sure that the enjoyment I had from the beauty helped me greatly. ${ }^{76}$

While the prisoners' movements and food were limited, the guards were unable to completely control how they viewed their environment. Although Thompson suggested that some POWs were unable to enjoy the scenery, either due to camp restrictions or their own mental state, his choice to see the good in his situation was a remarkable act of defiance. Whereas his statement on the illnesses which were enveloping the camp conjured distressing images, when he talked about the landscapes, there was a sense of peacefulness which was untouched by the harshness of human conflict.

Mackie found it harder to detach the area's natural beauty from his predicament as a POW. Moreover, he noted that because of the tropical conditions in Singapore which saw the "sun beat down mercilessly, punctuated at times by deluges of rain accompanied by deafening crashes and rolls of thunder and brilliant flashes of lighting, there was not much serene beauty 
for us to contemplate and draw a measure of comfort from." ${ }^{, 77}$ Still, he enjoyed looking at the "glorious and ever-changing sunsets ranging from pale pastel blue and gold to deep grey thunder-clouds tinged with edges of angry red."78 Mackie's change in mood when describing the progression of the day into night reflected a greater degree of autonomy as the day's tasks were completed and the guards became less prominent. Moreover, nightfall opened up another pastime for the prisoners to enjoy; stargazing. Mackie reasoned that "Man has always been fascinated by the night sky and we were doubly so as we looked for something enduring in our miserable and uncertain lives." 79 Also in Singapore, Tompkins remembered "The cloud effects and sunsets seen over the prison walls were very beautiful, and a great delight. Many people sat outside to watch the stars, and at times we thought we saw the Southern Cross." ${ }^{\prime 0}$ Stargazing or simply enjoying the scenery may seem like an insignificant act of resistance, but mental escapes were often the only means to combat the enemy. When POWs were starved or beaten, survival became the ultimate way to rebel. And because survival was predicated on ensuring one's mental state, as well as one's physical health, enjoying sights like sunsets was a way to resist the pressures of captivity. Tompkins simply summarised the importance of watching the sunset by defiantly stating that "It was something the Japanese could not take away from us." 81

Tompkins was particularly enamoured of her surroundings, because she spent her spare time painting anything she thought was "picturesque or worth recording." ${ }^{2}$ While it may seem strange that POWs found meaning within the deprivations of captivity, Lizzie Oliver argued that creative works, like paintings, were an essential means of recording testimony. ${ }^{83}$ In her study of the artwork created by Charles Thrale during his captivity, she concluded that illustrating allowed him to "step back and assess the nature of the deprivation he was suffering, and appease the 'gnawing in my stomach' with the aesthetic and spiritual satisfaction of his art." ${ }^{84}$ Tompkins experienced a similar escapism, even though her fellow captives questioned why she wanted to portray their experience in a positive light. Despite their reservations, she was undeterred and recalled that "The effect of light and shade in some parts of the prison was interesting. There was a remarkable chimney, and the cloud effects behind this chimney were very spectacular. . . My interest in painting and gardening was a God-send to me." 85 In her eyes, the mundane aspects of captivity were recast as points of interest. This newfound sense of purpose to paint allowed her to resist the pressures of her prolonged imprisonment. On a particularly rainy day Tompkins and a friend decided to spend their time painting. Due to the weather, they were limited to their immediate surroundings, thus decided to illustrate the nearby dustbins. Regardless of this limited subject material, Tompkins remembered that "We were told that we were the two happiest people in the prison on that day because we were so absorbed in our painting." 86

Captives in Asia endured a more gruelling experience than their European counterparts. There was less food, and they were subjected to more brutal punishments. Still, like POWs in Europe, they resisted the pressures of captivity through various forms. This paper acknowledges that physical escapes were rare in Asia, but it has shown that POWs sabotaged work placements. Whether it was working slowly or breaking equipment, this form of resistance closely aligned with the prisoners' desire to be seen as making a contribution to the war effort. Although these acts were fairly common in POW accounts, with most authors ensuring that readers were aware that they were not willing workers, it was more likely that acts of resistance centred on nonaggressive techniques. The way in which Bertram engaged in poetry, Mackie studied at Changi University, and Tompkins painted her surroundings testified to the power of nonconfrontational rebellion. Through these activities, the prisoners re-engaged with aspects of 
their past lives, which were entirely different to their current situation as captives in foreign lands. This assertion of self is the basis of this paper's argument that POWs resisted captivity. While some may suggest that these actions fall short of typical acts of resistance, when the context of captivity is understood it is apparent that efforts to retain aspects of identity, to refuse to submit to despondency, and to simply survive were instrumental to one's ability to endure a dehumanising experience.

\footnotetext{
${ }^{1}$ James Bertram, The Shadow of a War: A New Zealander in the Far East 1939-1946 (London: Victor Gollancz, 1947), 105.

${ }^{2}$ W. Wynne Mason, Official History of New Zealand in the Second World War 1939-1945: Prisoners of War (Wellington: War History Branch, Department of Internal Affairs, 1954), 160.

${ }^{3}$ Mason, Prisoners of War, 7.

${ }^{4}$ Bertram, Shadow of a War, 135.

${ }^{5}$ Christina Twomey, "Emaciation or Emasculation: Photographic Images, White Masculinity and Captivity by the Japanese in World War Two," Journal of Men's Studies 15 (2007): 300; Stephen Garton, "'Fit Only for the Scrap Heap': Rebuilding Returned Soldier Manhood in Australia after 1945," Gender and History 20, no. 1 (2008): 52; Peter Monteath, P. O. W. Australian Prisoners of War in Hitler's Reich (Sydney: Pan Macmillan, 2011), 430.

${ }^{6}$ Brian MacArthur, Surviving the Sword: Prisoners of the Japanese 1942-45 (Great Britain: Time Warner, 2005), 4.

${ }^{7}$ Christina Twomey, "Prisoners of War of the Japanese: War and Memory in Australia," Memory Studies 6 (2013): 322.

${ }^{8}$ W. Wynne Mason to William Russell, 14 November 1947, R16801402, Archives New Zealand (ANZ), Wellington, New Zealand.

${ }^{9}$ Far East POW Questionnaires, R16801403-R16801405, 1947, Archives New Zealand, Wellington, New Zealand.

${ }^{10}$ Gladys Tompkins, Three Wasted Years: Women in Changi Prison (Hamilton: Felicity Tompkins, 1977), 13.

${ }^{11}$ Tompkins, Three Wasted Years, 14.

${ }^{12}$ Tompkins, Three Wasted Years, 22.

${ }^{13}$ Tompkins, Three Wasted Years, 24.

${ }^{14}$ Christina Twomey, "POWs of the Japanese: Race and Trauma in Australia, 1970-2005," Journal of War and Cultural Studies 7, no. 3 (2014): 192; Gavan Daws, Prisoners of the Japanese: POWs of World War II in the Pacific (Carlton North: Scribe, 2004), 17.

${ }^{15}$ John Mackie, Captain Jack, Surveyor and Engineer: The Autobiography of John Mackie

(Wellington: New Zealand Institute of Surveyors, 2007), 225.

${ }^{16}$ Mackie, Captain Jack, 223.

${ }^{17}$ D. O. W. Hall, Official History of New Zealand in the Second World War 1939-1945: Prisoners of Japan (Wellington: War History Branch, Department of Internal Affairs, 1949), 3.

${ }^{18}$ Bertram, Shadow of a War, 141.

${ }^{19}$ Bertram, Shadow of a War, 145.

${ }^{20}$ Bertram, Shadow of a War, 145.

${ }^{21}$ Bertram, Shadow of a War, 145.

${ }^{22}$ Statement of Signalman Nathan Jaffe, 6 June 1946, Casualties - War crimes by Japanese against POW [Prisoners of War] Incidents - Evidence re etc, R22439794, ANZ, Wellington, New Zealand, 2.

${ }^{23}$ Statement of Flight Officer Donald Duff, June 1946, Casualties - War crimes by Japanese against POW [Prisoners of War] Incidents - Evidence re etc, R22439794, ANZ, Wellington, New Zealand, 12.
} 
${ }^{24}$ Statement of Sergeant Guy Herdman, 10 June 1946, Casualties - War crimes by Japanese against POW [Prisoners of War] Incidents - Evidence re etc, R22439794, ANZ, Wellington, New Zealand, 1. 25 "New Zealand Coastwatchers Executed by the Japanese," Ministry of Culture and Heritage, New Zealand History, https://nzhistory.govt.nz/page/nz-coastwatchers-executed-japanese, updated 11 July 2017.

${ }^{26}$ Statement of Leading Aircraftman Samuel Meredith, 19 June 1946, Casualties - War crimes by Japanese against POW [Prisoners of War] Incidents - Evidence re etc, R22439794, ANZ, Wellington, New Zealand, 2.

${ }^{27}$ Statement of Sergeant Robert Ravenwood, 7 June 1946, Casualties - War crimes by Japanese against POW [Prisoners of War] Incidents - Evidence re etc, R22439794, ANZ, Wellington, New Zealand, 4.

${ }^{28}$ Statement of Duncan McCallum, 4 June 1946, Casualties - War crimes by Japanese against POW [Prisoners of War] Incidents - Evidence re etc, R22439794, ANZ, Wellington, New Zealand, 1.

${ }^{29}$ Statement of Flight Lieutenant Ronald Millar. 31 May 1946, Casualties - War crimes by Japanese against POW [Prisoners of War] Incidents - Evidence re etc, R22439794, ANZ, Wellington, New Zealand, 1.

${ }^{30}$ Jaffe, Casualties, 3.

${ }^{31}$ Jaffe, Casualties, 3.

${ }^{32}$ Jaffe, Casualties, 3.

${ }^{33}$ L. S. Jones, The Life and Times of a Mining Engineer (Wellington: L. S. Jones, 1998), 38.

${ }^{34}$ Tom Woods, The Three Wings: Cliff Emeny's Story (New Plymouth: Zenith, 2004), 212.

${ }^{35}$ Woods, The Three Wings, 214-15.

${ }^{36}$ Bertram, Shadow of a War, 167.

${ }^{37}$ Mackie, Captain Jack, 244.

${ }^{38}$ Mackie, Captain Jack, 244.

${ }^{39}$ The death rate for Allied prisoners in Asia was 27 percent compared to 4 percent in German camps. MacArthur, Surviving the Sword, 2.

${ }^{40}$ Ralph Burton Goodwin, Escape from the Japanese: The Amazing Story of a PoW's Journey from Hong Kong to Freedom (Yorkshire: Frontline, 2015), 24.

${ }^{41}$ Goodwin, Escape from the Japanese, 27.

${ }^{42}$ Bertram, Shadow of a War, 149.

${ }^{43}$ Meredith, Casualties, 2.

${ }^{44}$ Mackie, Captain Jack, 240.

${ }^{45}$ Mackie, Captain Jack, 241.

${ }^{46}$ Bertram, Shadow of a War, 151.

${ }^{47}$ Claude Thompson, Into the Sun (New Zealand: Claude Thompson, 1996), 48.

${ }^{48}$ Major Robert Horker, Attachment X, Casualties - War crimes by Japanese against POW [Prisoners of War] Incidents - Evidence re etc, R22439794, ANZ, Wellington, New Zealand, 2.

${ }^{49}$ Woods, The Three Wings, 228.

${ }^{50}$ Woods, The Three Wings, 229.

${ }^{51}$ Woods, The Three Wings, 230.

${ }^{52}$ Robert S. La Forte, "Resistance in Japanese Prison Camps during World War II," The Journal of American-East Asian Relations 12, nos. 1-2 (Spring-Summer, 2003), 106.

${ }^{53}$ Kevin Blackburn, The Sportsmen of Changi (Chicago: University of New South Wales, 2012), 124.

${ }^{54}$ Midge Gillies, The Barbed-Wire University: The Real Lives of Allied Prisoners of War in the Second World War (London: Aurum, 2011), xvi.

${ }^{55}$ Woods, The Three Wings, 240-41.

${ }^{56}$ Mackie, Captain Jack, 249.

${ }^{57}$ Mackie, Captain Jack, 253.

${ }^{58}$ Jones, Mining Engineer, 58.

${ }^{59}$ Tompkins, Three Wasted Years, 65.

${ }^{60}$ Mackie, Captain Jack, 247.

${ }^{61}$ Mackie, Captain Jack, 287. 
${ }^{62}$ Mackie, Captain Jack, 289.

${ }^{63}$ MacArthur, Surviving the Sword, 187.

${ }^{64}$ Tompkins, Three Wasted Years, 56.

${ }^{65}$ Thompson, Into the Sun, 40.

${ }^{66}$ Thompson, Into the Sun, 66.

${ }^{67}$ Duff, Casualties, 7.

${ }^{68}$ Philippa Kelly, "'How I May Compare/ This Prison Where I live unto the World': Shakespeare in a Changi Prison," Journal of the Australasian Universities Language and Literature Association 95, no. 1 (2001): 20.

${ }^{69}$ Kelly, "How I May Compare," 21.

${ }^{70}$ Bertram, Shadow of a War, 168.

${ }^{71}$ Bertram, Shadow of a War, 169.

${ }^{72}$ Tompkins, Three Wasted Years, 51.

${ }^{73}$ Mackie, Captain Jack, 245.

${ }^{74}$ Mackie, Captain Jack, 246.

${ }^{75}$ Thompson, Into the Sun, 63.

${ }^{76}$ Thompson, Into the Sun, 66.

${ }^{77}$ Mackie, Captain Jack, 292.

${ }^{78}$ Mackie, Captain Jack, 292.

${ }^{79}$ Mackie, Captain Jack, 292.

${ }^{80}$ Tompkins, Three Wasted Years, 50.

${ }^{81}$ Tompkins, Three Wasted Years, 50.

${ }^{82}$ Tompkins, Three Wasted Years, 48.

${ }^{83}$ Lizzie Oliver, "'What our Sons Went Through': The Connective Memories of Far Eastern Captivity in the Charles Thrale Exhibition, 1946-1964," Journal of War and Culture Studies 7, no. 3 (August 2014): 241.

${ }^{84}$ Oliver, "What our Sons Went Through," 241.

${ }^{85}$ Tompkins, Three Wasted Years, 48.

${ }^{86}$ Tompkins, Three Wasted Years, 49. 